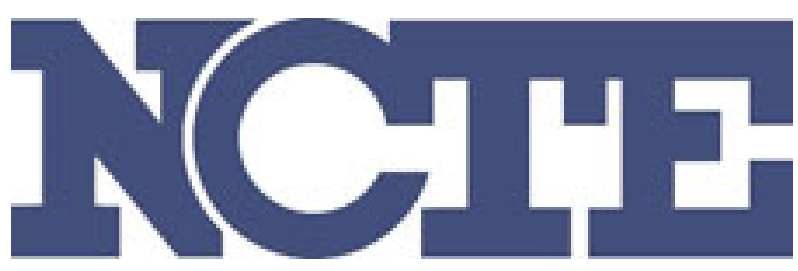

Fist Fights, Guns, and the Art of Teaching English

Author(s): Lawrence Baines

Source: The English Journal, Vol. 84, No. 5 (Sep., 1995), pp. 59-64

Published by: National Council of Teachers of English

Stable URL: http://www.jstor.org/stable/820011

Accessed: $21 / 11 / 2014$ 17:43

Your use of the JSTOR archive indicates your acceptance of the Terms \& Conditions of Use, available at

http://www.jstor.org/page/info/about/policies/terms.jsp

JSTOR is a not-for-profit service that helps scholars, researchers, and students discover, use, and build upon a wide range of content in a trusted digital archive. We use information technology and tools to increase productivity and facilitate new forms of scholarship. For more information about JSTOR, please contact support@ jstor.org.

National Council of Teachers of English is collaborating with JSTOR to digitize, preserve and extend access to The English Journal. 


\section{Fist Fights, Guns, and the Art of Teaching English}

Lawrence Baines

ducation can flourish only in the presence of certain fundamental endowments of mind and spirit. Education is possible for the student who has selfesteem, a belief that the future will be better than the past, the desire to become a free and autonomous adult. To the extent that any of these qualities is missing, the work of an educator becomes more difficult and less productive. (Howe 1991, 59)

In the middle school down the street from where I live, a seventh-grade English teacher was assaulted on the last day of class by one of her students. The student, John, a 14-year-old boy with a record of two previous convictions in juvenile court for armed robbery and assault (off campus), repeatedly pummeled the teacher with his fists and then kicked her after she fell on the ground. A crowd of students gathered around the scene and cheered on the 14-year-old with the exception of one female student, who ran to retrieve the assistant principal.

By the time the administrator arrived upon the scene, the teacher was unconscious, but John was still kicking her. After a short scuffle, John was restrained by the assistant principal and a physical education teacher (who happened by at the time) from doing further damage. The English teacher had to be hospitalized for several weeks as a result of the beating. Unbelievably, she had never been informed that the student had a previous criminal record. She only knew that John had gotten into several fights at school and had, in fact, just returned to school from a three-day suspension to attend the last day of class.

Of course, television and print journalists flocked to the school to get the gory details as news of the attack spread. Eventually, journalists and television crews gathered in the principal's office to report his response. During an interview with a television anchorperson, the principal said, "We will look into the alleged attack and seek to understand exactly what went on, how this fight came about." The principal also said that he and his staff would look into the "dreadful accident" (as he called it) and base a decision about John's future in the district after "both sides had a chance to tell their stories."

After the principal's response to the assault was aired on television, an immediate public outcry erupted over the principal's noncommittal nonaction. The next morning the superintendent of schools announced on television that John would be "suspended from classes immediately" (even though the assault occurred on the last day of school). Seven months and a trial later, the 14-year-old was tried as an adult and sent to jail for three years. To the surprise of no one, the English teacher, back at home after a two-week hospital stay, announced her retirement from teaching.

\section{THE DILEMMAS \\ OF SCHOOL VIOLENCE}

Part of the difficulty in controlling the spread of violence in schools is that most teachers and administrators do not particularly care to admit that some students have the potential for violent behavior. Certainly, most English teachers would rather discuss the rhythm of The Waste Land, a superb student paper, or the symbolism in Beloved rather than go over details about what to do when a 14-year-old wants to batter your face with his fists. Learning when and how to intervene when a student exhibits disruptive, assaultive behavior has become a matter of survival for many teachers in American schools today.

Insuring the security of students and teachers has put a further strain on already fiscally-troubled school systems. No one really wants to have to install metal detectors at the front door, as some $20 \%$ of urban schools have done. No one would rather spend funds for more police officers on campus rather than for more teachers or improved school facilities, although $70 \%$ of school districts now report using police to patrol schools (National League of Cities 1994). No one would rather spend money 
training English teachers how to react when a student wields a knife. But, the precedence and prevalence of violence has necessitated that many schools shelve loftier academic goals in favor of concentrating on carving out a safe place for children to spend their day.

\section{IDENTIFYING STUDENTS WITH VIOLENT TENDENCIES}

Because of the rise in the mainstreaming of special needs students and the concomitant legal pressure to maintain privacy for all students, some teachers (such as the English teacher in the story above) are not informed of the students in a class who may require special handling, or even pose a threat. In general, violent students tend to be male and openly aggressive, with long histories of disruptive and oppositional behavior.

In terms of the number of arrests of adolescents in America, for every age group under the age of 21 (the categories being those under 10 years of age, 10-12, 13-14, $15,16,17,18,19,20,21)$, males account for $85 \%$ of all violent crimes and about $75 \%$ of all property crimes. The only exception to the $75 \%$ rule for males is in the 13-14 year old group, where large numbers of $\mathrm{fe}$ male runaways drive the number of female property arrests up markedly (U.S. Department of Justice 1993).

In studies which have analyzed students who have been suspended from school for various offenses, it has been found that most of the students who are suspended from school have histories of serious misconduct (Arora and Thompson 1987, Baines 1993, Besag 1989, Committee on Education and Labor 1993, Olweus 1983). While not surprising, the pattern of the same students receiving most school suspensions and expulsions has eerie similarities to the findings of Marvin Wolfgang (1992), who has claimed that less than $10 \%$ of criminals commit about two-thirds of all crime.

I offer the following stories of three young men-Benny, Stuart, and Adamwho have been involved in violent encounters at school. I suspect that my observations of these three males might be generalizable to other American males who live their lives on the edge of violence.

\section{BENNY}

In September 1993, two colleagues and I began a year-long case study of an award- winning teacher-Karen Masterson-at a highly-acclaimed middle school in Texas. We were looking for the effectiveness of the integration of technology in instruction. After a few days of observations, it became apparent that the teacher in our study and other teachers at the school were not as interested in using technology as they were in simply keeping some semblance of control over the events occurring in their classrooms. The experiment could have easily turned into a case study of one particularly noticeable young man, a transfer student from California named Benny.

Benny looked to be at least two years older than any other student at the school and was the center of attention wherever he went. He threatened some students, got into fist fights with others, often refused to cooperate with his teachers, and required constant close supervision by teachers in all of his classes. Masterson (a teacher at the secondary level for 14 years) noted Benny's threatening demeanor and conferred with the counselor about him after his first day in English class and on several subsequent occasions.

She found out that Benny lived with his father, a divorced man who worked odd hours and could seldom be reached by telephone. When the counselor or Masterson finally reached the father to set up an appointment, he would agree to attend meetings but would never show up. As the year progressed, Masterson became increasingly worried that Benny might explode in her class and harm her or one of her students. She urged the counselor to move Benny to a self-contained classroom, but the counselor said that she was waiting on Benny's files from California.

One day, Benny appeared in Masterson's English class with a transfer slip signed by the counselor. Not only had Benny remained in Masterson's English class, he was also added to the roll in her reading class. Later, when Masterson indicated her surprise that Benny was added to her English class, she was told that Benny's files had arrived. Apparently, Benny was labeled E.D. (emotionally disturbed), and the counselor thought that his needs would best be met by Masterson serving as both his reading and his English teacher. Masterson spent the rest of the year filling out much paperwork on Benny, watching him closely, and sending 
him to the office whenever he seemed on the verge of losing his self-control (which happened once or twice every week).

Despite such close supervision, Benny was involved in numerous fights in his first few months at the school. Although he was called into the office daily for threatening students, most students were too frightened of Benny to report him. The principal's usual response after hearing about a threat from Benny was to give him two or three days of in-house suspension. When Masterson suggested to the principal that this solution seemed to be ineffective with Benny, the principal told her that he would stop using in-house suspension as punishment.

Instead of devising an alternate plan for dealing with Benny's misbehavior, the principal admonished Masterson to "start reinforcing Benny for his good behavior" and to stop sending him to the office. Masterson attempted to abide by the principal's request, but sent Benny to the office when she thought he was becoming potentially dangerous to her or her students. Routinely, the principal would send Benny back to the classroom ten or fifteen minutes later with the note, "Spoke to Benny about his behavior. Please allow back in class."

One day, when 170-pound Benny threatened a 60-pound girl in class and looked as if he was going to strike her, Masterson intervened and sent Benny to the principal's office, as she had done innumerable times during the year. This time, however, Benny did not return with a note from the principal, but stayed away the entire period. After the class was over, a teacher from down the hall came and told Masterson the story. During a conversation with the principal, Benny became angry and took a swing at him, grazing him in the eye before he was restrained. After the incident, the principal recommended that Benny be suspended from school for ten days.

\section{STUART}

In 1990, I taught middle school in an affluent suburb of Houston, Texas. Stuart was a student who attended half of his classes in a self-contained room and the other half in regular classrooms. Because I taught four sections of English and two sections of physical education, I had Stuart in two different classes and got to know him fairly well. It was well-known through out the school that Stuart was a volatile student who could erupt in a flurry of violence at any time. Teachers were individually notified by the special education teachers that Stuart could potentially pose a problem for teachers or one of our students.

Stuart came from an affluent family, who inhabited a large two-story house down the street from the school. Stuart's older sister had been a cheerleader and an honor student, and his older brother had been a popular football player who was a $B-C$ student. According to his parents, Stuart had struggled socially and academically since kindergarten. He had been categorized as emotionally disturbed with multiple learning disabilities in elementary school. He had few friends and did poorly in school.

I had never seen Stuart in one of his infamous emotional outbursts, so I pledged to myself that Stuart would receive fair and caring treatment from me in my class. I knew the research on the importance of teacher expectations on student behavior, and I thought that if I expected Stuart to behave he would do so. For the first two weeks, I felt like a genius. Although Stuart would get off-task, whenever I would gently prod him to finish his assignments and not to disrupt other students, he seemed, at times, to pay attention to me. Sometimes, he even stopped disrupting long enough for other students to work on their assignments.

On Tuesday of the third week of school between fourth and fifth periods, Stuart came into my room, confronted a small, quiet boy named Robert and shouted, "Motherfucker!" Then, he overturned desks, kicked Robert in the leg, and shouted more obscenities. Standing by my door as teachers at my school were supposed to do between classes, I walked into the classroom and told everyone who had the misfortune to arrive early to clear the room. Stuart said that if Robert tried to leave, he would kill him. He pointed his finger in Robert's face. As the other students quickly filed out, I sent one student to run for the assistant principal and another for the special education teacher in the next building.

As Stuart turned to pick up a desk before throwing it in Robert's direction, I picked Robert out of his seat and carried him into the hallway. Stuart continued to kick, scream, and throw desks, but he didn't come
The

precedence

and

prevalence of

violence has

necessitated

that many

schools shelve

loftier

academic

goals in

favor of

concentrating

on carving out

a safe place

for children

to spend

their day. 
after us. The assistant principal and the special education teacher arrived at my classroom a minute later. Together, the three of us talked to Stuart. Then two of us grabbed him by an arm and tried to restrain him while I moved furniture out of the way. As the assistant principal restrained Stuart, the young man sank his teeth into the assistant principal's forearm and, for some seconds, refused to release his jaws. Finally, the assistant principal and the special education teacher escorted Stuart to the "time-out room" in the special education center, where he ranted and kicked in solitude until he lost energy. The assistant principal received six stitches in his forearm from Stuart's bite.

Stuart stayed in the special education classroom as a kind of in-house punishment for the next three days; then he was returned to his regular classes. The first day of his return, he erupted again, this time in his first period art class. At the request of the administration and with the consent of his parents, Stuart was taken out of school and referred to a private hospital for psychological counseling (which was paid for by the district). My student Robert and I never saw him again.

\section{ADAM}

Adam was a student in a remedial English class during my first year as a teacher in an urban area in the South. Adam was quiet, unassuming, and put forth genuine effort at trying to learn. Because he lived in a particularly notorious, small housing project in the shadows of downtown, he received some teasing at school from his peers. One student in class was fond of saying that Adam's neighborhood contributed to half of the crime in the city. Sadly, the comment was a fairly accurate one.

Adam lived with five siblings in a twobedroom apartment with his grandmother, a delightful 67-year-old woman who, no matter how hard she tried, could not keep up with her grandchildren. No one was quite sure what happened to Adam's mother or his father. Adam quite obviously loved his grandmother, and she tried to direct his activities in a positive way, but she could not control Adam's younger brothers and sisters, let alone Adam, the oldest and most independent of the bunch.

Although Adam wasn't especially good at playing the "dozens," a game in which students relentlessly hurled insults at each other, he often found himself in the middle of "word wars" with the king of the insult, Daniel. For the most part, Adam shared in the game of insults and would laugh with his peers when Daniel made a particularly stinging remark, even if one happened to be at his own expense. Although students loved to verbally spar with each other about the other's clothes, hair, friends, house, car, brothers and sisters, jewelry, the only unmentionable topic, the subject that no student dared mention without getting ready to defend himself with his fists, was mother. Adam, especially, reacted vehemently when anyone mentioned his mother. He'd always warn whoever was trying to mess with him, "You don't be talkin' about my mama" loudly enough to let the student and me know that if the offending individual did not cease the nasty comments and apologize immediately, Adam "was about to go crazy on his head" (which meant Adam was getting ready to pounce). Most students shut up and apologized.

One day in lunch line, a student called Adam's mother a name, and Adam beat the student's face and body so badly that the student had to be taken away in an ambulance. When the assistant principal tried to break up the fight, Adam thought he was handled too roughly, and he ended up taking a punch at him, too.

Adam was suspended from school for five days for sending one student to the hospital and for taking a swing at the assistant principal. When he returned to school, the assistant principal insisted that he stay in inhouse suspension for the remainder of the grading period-three weeks.

Again, Adam thought the sentence unfair. He left in-house suspension, told the inhouse supervisor that he was going to kill him, went home, got a gun, and then came back up to school. When Adam returned and walked through the door of the building reserved for in-house suspension, he had the gun out, ready to fire. At the time of Adam's arrival, the in-house supervisor happened to be just inside the entrance, sharpening a pencil. He saw the barrel of Adam's gun before he ever saw Adam and was able to knock it out of his hand before the gun was fired. The in-house supervisor (an ex-Army sergeant, by the way) restrained Adam until 
police arrived. Adam was expelled from school for the remainder of the year and eventually spent some time in a juvenile detention center. He never returned to school.

\section{ADOLESCENTS AND CRIME: IN SCHOOL AND OUTSIDE OF SCHOOL}

Currently, only three states-California, Connecticut, and South Carolina-mandate that crimes in schools be reported, so data concerning violence in the schools must be pieced together through surveys and police reports. A survey by the National League of Cities (November, 1994) revealed that onefourth of all city schools reported at least one act of serious violence that resulted in a student being hospitalized or killed. Forty-one percent of urban schools reported at least one occurrence of serious violence or killing.

Consider some statistics concerning violence, crime, and adolescents in and out of school settings (compiled from U.S. Department of Justice 1993, Committee on Education and Labor 1993, and National League of Cities 1994):

- The rate of violent crime in America is higher than in any other industrialized country.

- Persons under the age of 15 accounted for $5.8 \%$ of the persons arrested $(689,877$ persons) in 1992, while persons under the age of 18 accounted for $16.3 \%$ of the persons arrested (1.95 million persons).

- About 16,000 thefts or violent crimes occur each school day, or about one incident every six seconds.

- Sixteen percent of students reported having been threatened with a weapon at school. Six percent of students have been injured by a weapon while at school.

- One in five teachers reported being verbally abused, $8 \%$ verbally threatened, and $2 \%$ actually physically attacked during the 1992 school year.

- Teachers in urban areas are twice as likely to be verbally and physically assaulted as teachers in rural areas.

- In 1992, in New York City, there were 1,880 assaults and 2,416 incidents of weapons violations.

- About $8 \%$ of students in grades 9-12 reported that they had been in at least one fight in which they sustained serious injuries (requiring hospitalization).

- In a survey done by the Centers for Disease Control, $5 \%$ of students surveyed admitted that they brought a gun to school.

\section{CURRENT RESPONSES TO VIOLENCE IN SCHOOLS}

While the overall rate of property crime per capita has leveled off since 1982, during the same period the arrest rate has increased $93 \%$ for juveniles accused of murder, $72 \%$ for aggravated assault, $97 \%$ for vehicle theft, and $24 \%$ for forcible rape (U.S. Department of Justice 1993). It is no secret that a great majority of inmates in prisons are high school drop-outs. In an effort to reduce the drop-out rate, most states have raised the legal age that students may withdraw from school and begun tying positive consequences, such as the attainment of a driver's license, to earning a high school diploma. While the drop-out rate has slowed a bit, keeping potential drop-outs in school longer has made the school environment a less safe place. Because funding for schools is linked to enrollment numbers and because it is politically astute for school administrators to promote the ideal that "all children can learn," school bureaucracies usually do what they can to keep as many students coming to school as possible, even potentially dangerous students.

This has meant the use of creative ideas to get some students to attend school. Some school districts have begun to give cash awards for attendance. Some wealthier school districts have developed alternative schools, where chronically disruptive students can attend small classes in a flexible, highly supervised environment. Due to shrinking budgets, soaring legal fees, and sensationalistic media coverage, most schools have been forced to adapt a "damage control" approach to curbing violence. Changes in school policy seem to only occur following a catastrophe - a shooting, a bloody fight, a rumble. As a result, students and teachers in many schools spend more time worrying about safety than about learning anything.

\section{APPROACHES TO VIOLENCE PREVENTION}

According to the Nonviolent Crisis Intervention Institute (1987), the best response to a potentially violent situation involves six considerations:

1. Getting help from a fellow teacher or an administrator;

2. Maintaining control of your own behavior;

3. Enforcing limits;

4. Removing the audience;

\section{Changes in school policy seem to only occur following a catastrophe- a shooting, a bloody fight, a rumble.}




\section{The gravest danger is in doing nothing at all.}

5. Using simple language to communicate with the student; and

6. Avoiding a power struggle with the student.

Of course, not every violent outbreak is controllable. The English teacher mentioned at the being of this article (who was beaten by a 14-year-old on the last day of school) told John that he looked "very nice" just before he erupted into a violent tirade.

Mike Rose and Joe Clark represent two divergent approaches towards teaching difficult, potentially violent individuals. In Lives on the Boundary (1986), Rose details how he successfully taught a number of students who had experienced very little previous success in public schools. Indeed, under his persistent care and individual attention, students considered uneducable made extraordinary intellectual progress. Rose, who worked with students who spoke little English, junior high drop-outs, hardcore prisoners, and schizophrenics residing in state mental institutions, found that all of his students possessed the capability and the desire to learn to some degree.

At the other extreme, Joe Clark helped transform a chaotic, crime-ridden high school in New Jersey into a well-organized, high-achieving, secure school by kicking out students guilty of drug use, violence, or crime. Clark (who gained fame through the motion picture based on his experience, Lean on $\mathrm{Me}$ ) locked all the doors into the school except the main entrance, patrolled the corridors with a baseball bat, and instituted a challenging, academic curriculum. As a result of Clark's efforts, test scores at the school climbed, crime dropped, and teacher morale improved markedly.

\section{CAN ALL STUDENTS LEARN?}

During the past decade or so, American school systems have been alternately enamored with providing special services for violent students and throwing them in jail. Certainly, the vision that all students are willing and able to learn is the ideal most educators heartily endorse. But, is such an ideal realistic?

Mike Rose never worked in a secondary public school where he would have seen 195 students or so of varying abilities each day; where he would have had to eat a sandwich during a 25-minute lunch while hovering around in the school cafeteria supervising hundreds of adolescents also eating lunch; where he would have had to sit in meetings with parents, counselors, administrators, and team members before and after school; where he would have had to consider students' high school exit exams, his yearly evaluation as a teacher, his students' SAT scores; where he would have had to serve as debate club sponsor, junior class sponsor, and coach of the cross-country teams. Indeed, most of the education encounters Rose had with students were one-on-one sessions of variable duration. No bells, no fire drills, no Pledge of Allegiance, no tardy counts, no 36 students waiting outside of the door for the next class.

Perhaps the most pressing dilemma for educators today is balancing the success of the potentially dangerous student against the welfare of the great majority of other students in school. Whether a school decides to help students through specially designed classes, to train 'teachers in nonviolent intervention techniques, or to expel and prosecute perpetrators of violence, the gravest danger is in doing nothing at all.

\section{Works Cited}

Arora, C. and D. Thompson. 1987. "Defining Bullying for a Secondary School." Education and Child Psychology 4.3: 110-120.

Baines, Coleen. 1993. The Frequency and Type of Disciplinary Referrals. Unpublished research. Austin, TX: University of Texas.

Besag, Valerie. 1989. Bullies and Victims in Schools. Philadelphia: Open University Press.

Committee on Education and Labor. 1993. Hearing Before the Subcommittee on Elementary, Secondary, and Vocational, Education, Serial No. 103-70. Washington D.C.: Government Printing Office. (Jun. 22).

Howe, Quincy. 1991. Under Running Laughter. New York: Free Press.

National League of Cities. 1994. "School Violence in America's Cities." Education Week (Nov. 23): 4.

Nonviolent Crisis Intervention. 1987. Participant Workbook. Brookfield, WI: National Crisis Prevention Institute.

Olweus, D. 1983. "Low School Achievement and Aggressive Behavior in Adolescent Boys." Human Development: An Interactional Perspective. Eds. D. Magnusson and V. Allen. San Diego: Academic Press.

U.S. Department of Justice, Bureau of Justice Statistics. 1993. Sourcebook of Criminal Justice Statistics, 1992. Washington, D.C.: U.S. Government Press.

Wolfgang, Marvin. 1992. "An Anti-Crime Solution: Lock Up More Criminals." Ed. E. Methvin. The Washington Post (Jan. 15).

Lawrence Baines teaches at Florida State University in Tallahassee. 